\title{
Employability Skills- student Self Assessment Of Strong And Weak Areas
}

\author{
Remadevi O.T. \\ Research Scholar, \\ Research and Development Centre, \\ Bharathiar University, Coimbatore, India
}

\section{Introduction :}

Competitive market environment, cutting-edge technologies, and rapid, continuous changes the world over, are demanding competence and capabilities to be reshaped and sharpened in tune with the global requirements. Employability skills of yesteryears are not sufficient for today's newly graduated engineers. Technical knowledge, skills and abilities, alone, even at the topmost level, possessed by a fresh engineer, are not adequate enough to face the present labour market challenges. $\mathrm{S} / \mathrm{he}$ is expected to have a combination of personal qualities, resource management skills, interpersonal skills and other attributes. S/he must be capable of deploying these skills as per the situational requirements and must also improve and hone these skills, qualitatively and quantitatively. The behavioural competencies should display these, as one climbs the career ladder.

India, as per the All India Council for Technical Education (AICTE) statistics, has 3384 engineering institutions and 1634596 student intake as of academic year 2013-2014 [1]. While we have a few good quality institutions and outcomes, reports from various corners reveal the deplorable quality of a substantial number of engineering institutions, with inferior outputs and outcomes. While many students have the potentials to develop, due to various factors, their employability skills seem to remain undernourished and under-developed.

\footnotetext{
Remadevi O.T.

Research Scholar,

Research and Development Centre,

Bharathiar University, Coimbatore, India
}

\author{
V. Ravi Kumanr \\ Professor \\ CMS Institute of Management Studies \\ Coimbatore, India
}

The word engineering means 'practical application of science to commerce or industry'. It can also be described as 'the discipline dealing with the art or science of applying scientific knowledge to practical problems'. From an engineering student's level, employability skills are the abilities, attitudes, skills and competencies one acquires through continuous efforts, from within and outside the campus, so as to equip him/her for an appropriate entry level position, that matches his/her qualification and aptitude . Institutions, policy makers and of all, the students themselves have to make sincere and effective efforts to make this happen. This paper presents a few of these skills-set expected by the employers from fresh engineering students. It further gives a brief account of the engineering student perceptions - their strong areas and weak areas within this skills-set. Before we learn the students' assessments, let us have a broad understanding of the academic expectations from an engineering student.

The following give the 'Learning Goals and Outcomes' from the US-based Accreditation Board for Engineering and Technology programs (ABET, 2014-2015). The engineering graduate is expected to demonstrate the ability to:

apply knowledge of mathematics science and engineering-design, and conduct experiments; analyse and interpret data-d e s ig n a s y s t e m, component or process to meet desired needs within realistic constraints ( constraints such as economic, ethical, health \& safety, manufacturability and sustainability)

- function on multi-disciplinary teams

- identify, formulate, and solve engineering problems 
communicate effectively

engage in life-long learning

use the techniques, skills and modern engineering

tools necessary for engineering practice

Apart from these abilities, 'understanding of professional ethical responsibility', 'the broad education necessary to understand the impact of engineering solutions in a global, economic, environmental and societal context', and 'knowledge of contemporary issues', are the other criteria under their 'Learning Goals and Outcomes' [2].

Having been a provisional member of the Washington Accord from 2007 to 2014 and a permanent member since 2014, India's National Board of Accreditation (NBA), has more or less similar criteria for accreditation [3], [4].

\section{Objectives}

The primary objective of this paper is to create awareness among the engineering students and other interested groups, about the employer expectations from a fresh engineering student. It further intends to present empirical evidence on the skill pattern perceived by students through identification of their own strong and weak areas under the employability skills-set. Identifying ones' own strengths and weaknesses, acts as a self motivator to learn and master the needed skills in the labour market. The study also tries to analyse the gender difference, if any, in the students' self assessment of strong and weak areas under the employability skills.

\section{Literature Review}

The reviews given here are employer perception studies undertaken at the University of Ulster, the Ireland, and also from Malaysia, and India.

Morgan and Gorman (2011) from the University of Ulster, highlight the importance of 'good communication skills' and 'team-working ability' for technical graduates' employability [5]. They also identify the significance of 'commercial awareness', as a key attribute in getting employment. Interestingly, they agree that the engineering students do not realise the significance of this attribute.

Hassan et al (2012) were interested in studying employer perceptions on employability skills of engineering students. The skills studied, based on the
Generic Students Attributes (GSA), established by the Ministry of Higher Education (MOHE), Malaysia, were: 1. Communication Skill (Verbal, Written), 2. Critical Thinking (Problem Identifying, analysing, solving), 3. Life-long Learning, 4. Moral Ethics and 5. Teamwork Skills. The findings elucidated that the students were low in critical thinking, team working skills and communication skills [6].

Blom and Saeki (2011), of the World Bank, studied the employability skill-set of newly graduated engineers in India, through an 'employer satisfaction survey'. The responses were collected from 157 employers. The research was carried out as part of the second phase of the Technical Quality Improvement Program (TEQIP-II). The results show that the employers perceived Core Employability Skills and Communication Skills to be very important. It further stated that only $36 \%$ of employers were satisfied with the skills of their engineering employees [7].

Of the 26 skills-set developed, they had selected many of these skills from the ABET and NBA learning outcomes criteria. Through factor analysis, they had grouped 25 of these skills into three major factors, as: 1. Core Employability Skills, 2. Professional Skills and 3. Communication Skills.

Table 1 skills/attributes under three distinct categories.

\begin{tabular}{|l|l|l|}
\hline Core Employability Skills & Professional Skills & Communication Skills \\
\hline Integrity & $\begin{array}{l}\text { Identify, formulate and } \\
\text { solve technical/engineering problems }\end{array}$ & $\begin{array}{l}\text { Written communication } \\
\text { Design and conduct experiments, } \\
\text { and analyse and interpret data }\end{array}$ \\
\hline Self-discipline & $\begin{array}{l}\text { Design a system, component } \\
\text { of process to meet desired needs }\end{array}$ & \\
\hline Reliability & $\begin{array}{l}\text { Use appropriate/modern tools, } \\
\text { equipment, technologies }\end{array}$ & Reading \\
\hline Self-motivated & $\begin{array}{l}\text { Apply knowledge of mathematics, } \\
\text { science and engineering }\end{array}$ & Communication in English \\
\hline Entrepreneurship Skills & Customer Service Skills & Technical Skills \\
\hline Teamwork & Knowledge of contemporary issues & Verbal Communication \\
\hline $\begin{array}{l}\text { Understands and takes direction } \\
\text { for work assignments }\end{array}$ & Creativity & $\begin{array}{l}\text { Basic Computer } \\
\text { Advanced Computer }\end{array}$ \\
\hline Willingness to learn & & \\
\hline Flexibility & & \\
\hline Empathy & & \\
\hline
\end{tabular}

\section{Research Methodology}

Survey methodology was used for the present study. The skills-set, used by Blom and Saeki (2011), with slight modifications, was incorporated in the questionnaire, for this part of the study. A three-point rating scale, with qualitative description, 'Very Important', 'Important' and 'Less Important', was used for rating the importance of these attributes. Listing the attributes centrally, the scale for rating importance was given on the left side. Another three-point scale 
with description, 'developed to a great extent', 'developed to some extent', and 'not developed at all', was used for rating the development of these skills. This scale was given on the right side of the attributes. Students were requested to mark how much they thought those skills were important in the employability sector and also to mark the extent they thought those twenty six attributes were developed in them. To identify strong and weak areas, instructions were given to further write down three skill areas they considered themselves strong and three skill areas they considered themselves weak and wanted to improve. This writing down part was included as it facilitated one more round of selection and weighing from the initial rating. This was administered directly to 225 final year engineering students, in their respective class rooms. The students belonged to two self-financing engineering colleges in Ernakulam District, Kerala State, India. Majority of them belonged to rural areas. They had four different core electives; Electronics and Communication (EC), Electrical and Electronics (EE), Computer Science, and Applied Electronics and Instrumentation (AEI). All the students present in a particular class during the data collection process, were given the questionnaire. An introductory explanation of the purpose of the study was given. Rejecting the incomplete ones, analysis was done for 219 student responses, with 94 boys (43\%) and 125 girls (57\%) constituting the sample. The data were collected during July - August 2014.

\section{Findings}

Students' perceptions of their own strong areas and the weak ones they wanted to improve varied widely. 'Self Discipline' scored the top with $35.6 \%$ considering it their strong area. A similar percentage of students (35.2) marked 'Verbal Communication in English' as their weak area. Only the skills which were identified by a considerable number of students are given here due to wide individual variations in the students' choices. Table 2 presents this picture on strong skill areas and table 3 gives that of weak areas.

The prominent skills among the strong ones were, 'self discipline', 'teamwork', 'honesty' and 'willingness to learn'. A close look at the gender difference in the choices of these skills shows that more girls perceived themselves strong in 'self-discipline', than boys. Chi square value also confirms this (the calculated value is more than the table value of 3.841 , for 1degree of freedom). The gender difference was not significant in the other skills.
Table 2. Top three Employability Skills considered strong by students

\begin{tabular}{|l|l|l|l|l|c|c|c|}
\hline \multirow{2}{*}{$\begin{array}{l}\text { Employability } \\
\text { Skills/Attributes }\end{array}$} & \multicolumn{3}{|c|}{ Skills in which students rated themselves as strong } & \multirow{2}{*}{$\begin{array}{l}\text { Chi } \\
\text { square } \\
\text { value * }\end{array}$} & \multicolumn{2}{|c|}{ Boys, N=94 } & \multicolumn{2}{c|}{ Girls, N=125 } & \multicolumn{2}{|c|}{ Total, N=219 } \\
\cline { 2 - 8 } & Number & $\%$ & Number & $\%$ & Number & $\%$ & \\
\hline Self -discipline & 26 & 27.6 & 52 & 41.8 & 78 & 35.6 & 4.5468 \\
\hline Teamwork & 27 & 28.7 & 41 & 32.8 & 68 & 31 & 0.4164 \\
\hline $\begin{array}{l}\text { Honesty, Integrity } \\
\text { and Dependableness }\end{array}$ & 28 & 29.8 & 35 & 28 & 63 & 28.8 & 0.1735 \\
\hline Willingness to learn & 23 & 24.5 & 29 & 23.2 & 52 & 23.7 & 0.0477 \\
\hline Basic computer & 27 & 28.7 & 24 & 19.2 & 51 & 23.3 & 2.7218 \\
\hline
\end{tabular}

Table 3. Skill areas in which students considered they are weak and wanted to improve.

\begin{tabular}{|c|c|c|c|c|c|c|c|}
\hline \multirow{2}{*}{ Employability Skills/Attributes } & \multicolumn{2}{|c|}{$\mathrm{N}=$ Boys 94} & \multicolumn{2}{|c|}{$\mathrm{N}=$ Girls 125} & \multicolumn{2}{|c|}{$\mathrm{N}=$ Total 219} & \multirow{2}{*}{$\begin{array}{l}\text { Chi square } \\
\text { value* }\end{array}$} \\
\hline & No. & $\%$ & No. & $\%$ & No. & $\%$ & \\
\hline Verbal Commenication in English & 42 & 44.7 & 35 & 28 & 77 & 35.2 & 22.938 \\
\hline $\begin{array}{l}\text { Advanced Computer (e.g. spreadsheets, } \\
\text { databases) }\end{array}$ & 25 & 26.6 & 31 & 24.8 & 56 & 25.6 & 0.094428 \\
\hline $\begin{array}{l}\text { Design a system, companent or processs to } \\
\text { meet desired needs }\end{array}$ & 17 & 18.1 & 40 & 32 & 57 & 26 & 5.388 \\
\hline Knowledge of Contemporary Issues & 23 & 24.5 & 30 & 24 & 53 & 24.2 & 0.00663 \\
\hline
\end{tabular}

'Verbal Communication in English', 'advanced computer', 'system design' and 'knowledge of contemporary issues' were the weak areas and also the ones they wanted to improve. The gender difference was also significant here, with more boys (around $45 \%$ of total boys in the sample) responding that they are weak and wanted to improve. Only $28 \%$ of the total girls had a similar choice. The calculated value of chi square, 22.938 being much above the table value of 3.841 , for 1 degree of freedom, confirm this statistically. None of the other skills were statistically significant for gender-based choice difference.

\section{Conclusion}

The final year engineering students from these colleges, in general, have either strong or moderate 'core employability' skills. This is a good sign in that it is more difficult to cultivate core employability skills, than professional or communication skills. The students' professional and communication skills need attention, and appropriate, need-based intervention from early semesters onwards. This would help them acquire most of the abilities envisaged under the ABET /NBA 'Student Outcome Criteria', which, in turn, would facilitate to gain employment, appropriate to their qualifications and aptitude.

\section{References:}

[1]All India Council for Technical Education. Statistics-Institutes-Intake. From www.aicte- 
india.org/downloads/growth Technical Institutio ns 310514.pdf

[2]ABET.Criteria for Accrediting Engineering programs, 2014-2015. From www.abet.org/eaccriteria-2014-2015, retrieved on 24/09/2014.

[3] W a s h i n g t o n A c c o rd. F r o m www.ieagreements.org/washington-accord

[4]National Board of Accreditation. From nbaind.org./En/1051/-nbas-accreditationparameters-criteria- \& processes.aspx

[5]Morgan, M. and O' Gorman, P. (2011). Enhancing the employability skills of undergraduate engineering students. From www. ineer.org.ineerbooks/2011-Innovations_V7, Ch. 18.

[6]Hassan, H., Zamberi, M., Khalil, S.N., Sanusi, N., Washari, F., Kamardzaman.A.A. (2012). Company perceptions on the employability skills of industrial training students. Journal of Technical Education and Training, Vol.4, No.2.

[7]Blom, A. and Saeki, H. (2011). Employability skill set of newly graduated engineers in India. In research report from www.worldbank.org 